\title{
Author Correction: Vulnerabilities of protected lands in the face of climate and human footprint changes
}

\author{
Nawal Shrestha (1), Xiaoting Xu, Jiahui Meng (10) \& Zhiheng Wang (1)
}

Correction to: Nature Communications https://doi.org/10.1038/s41467-021-21914-w, published online 12 March 2021.

In the original version of this Article, the maps in Figs. 1, 2, and 4, and Supplementary Figs. 1, 2, 3, and 4 omitted territories in the South China Sea. The maps have now been updated according to the territorial map guidelines of the authors' institutions in both the PDF and HTML versions of the Article. Springer Nature remains neutral with regard to jurisdictional claims in published maps and institutional affiliations.

Published online: 10 May 2021

\section{Additional information}

Supplementary information The online version contains supplementary material available at https://doi.org/10.1038/s41467-021-23423-2.

\footnotetext{
(c) (i) Open Access This article is licensed under a Creative Commons Attribution 4.0 International License, which permits use, sharing, adaptation, distribution and reproduction in any medium or format, as long as you give appropriate credit to the original author(s) and the source, provide a link to the Creative Commons license, and indicate if changes were made. The images or other third party material in this article are included in the article's Creative Commons license, unless indicated otherwise in a credit line to the material. If material is not included in the article's Creative Commons license and your intended use is not permitted by statutory regulation or exceeds the permitted use, you will need to obtain permission directly from the copyright holder. To view a copy of this license, visit http://creativecommons.org/licenses/by/4.0/.
}

(c) The Author(s) 2021 